\title{
The Educational Warning of the Dai People's Ancient Folk Songs in Talents Cultivation
}

\author{
Zhiqiang Mao \\ Marxism College \\ Yunnan University of TCM \\ Kunming 650500, P. R. China \\ E-mail: 823172115@qq.com \\ Meijun Ding \\ Marxism College \\ Yunnan University of TCM \\ Kunming 650500, P. R. China \\ E-mail:13233642@qq.com
}

\author{
Wen Zheng* \\ Asset Division \\ Yunnan University \\ Kunming 650500, P. R. China \\ E-mail:846635041@qq.com
}

\begin{abstract}
The Dai people's ancient folk songs are the collective wisdom crystallization in the Dai People's long-term social life practice. The Dai people have formed a set of standard system on regulating their own production, life and ideological behavior by the Dai people's ancient folk songs, and the educational warning is one of the important aspects of the Dai people's ancient folk Songs to play their own standard. The Dai people's ancient folk songs have some records of natural disasters, "bitter" in life, and "evil" in their behavior. The warning function of the Dai people's ancient folk songs always plays a moral teaching role through the form of whip and eulogize, and the educational warning function of the Dai people's ancient folk songs in the cultivation of talents is mainly through teaching. The moral education of music and the centralized teaching of ritual play a role.
\end{abstract}

Keywords: The Dai nationality; ancient folk songs; talents cultivation; warning.

\section{I.INTRODUCTION}

The Dai people's ancient folk songs are the crystallization of the wisdom in the long historical development and social practice. The Dai people have formed a set of standard system on regulating their own production, life and ideological behavior by the Dai people's ancient folk songs. The traditional ethics education of Dai nationality shows a kind of educational form with the characteristics of the nation by the Dai people's ancient folk songs.

\section{STARTING POINT: THE DAI PEOPLE'S} ANCIENT FOLK SONGS TAKE ON EDUCATIONAL WARNING FUNCTIONS

According to the connotation of education, we deem the function of education as the influence and effect of social activities on individual development and group development. One of the educational functions of the Dai people's ancient folk Songs in talents cultivation is the educational warning function. The Dai people's ancient folk songs are the poetry anthology of the Dai people in each period. The Dai Folk Songs include labor songs, ritual songs, Life songs, love songs, custom songs, blessing songs and nursery rhymes, and express their understanding of life, labor, love, marriage, morality and ideal in the form of ballad. There are a lot of warning education records. This article focuses on the warning function of the Dai people's ancient folk songs, analyzes its operable value, and explores its enlightenment to talents cultivation.

\section{THE WARNING CONTENTS: THREE KINDS OF EXPRESSION}

According to the different warning contents, this paper divides them into warning of natural disasters, "bitter" warning in life and a warning of "evil" in behavior.

\section{A. The Warning about Natural Disasters}

In the Dai people's ancient folk songs, such as "Flood", "Great fire", "Mountains fall and the earth splits", there are many records reflecting the disaster and hardship caused by nature in ancient times. 'the rock is washed away, the tree is washed down, the forest is submerged', 'Only a mountain, the top of the mountain is above the water, and the man who runs to the top of the mountain will leave a life, the people and animals that can't run die in the water', 'It is one hundred days, the great water is gone, the mountains become flat, the land becomes a river beach, the human havoc, not many living', 'poor man, almost extinct', 'In the history of the ancient people, there were two calamities included a fire burning the sky and a flood of water. the later generations do not forget, always remember'.[1] It is reflected, in the disaster caused by natural disasters, the ancestors of the Dai nationality can still explore the way of conquering nature by a brave spirit, a positive and undefeated attitude.

The Dai people formed a traditional ecological view of life and nature in a harmonious relationship with nature. Firstly, the formation of this ecological view is inseparable from the religious religion of the Dai people. In Buddhism, the concept of "no killing, equality of all living beings", the concept of "all things have spirit" in the original religion, namely, natural things and human beings are 
equal. All these contribute to the value judge and behavior orientation of the Dai People's respect and respect for nature and life. Here, all things like human beings are emotional in nature. People and nature are interdependent, harmonious and inseparable. For example, in the ancient folk song of the Dai people, there are some songs: 'no forests, no water, no water, no fields, no fields, no grain, no grain, no life.'[2] This expression reflects the idea and experience judge, summed up by the Dai people, of the harmonious co-existence of man and nature. Secondly, the Dai nationality formed a punishment system established and a responsibility system for natural life through a series of taboos. Because of the reverence for nature and life, the sense of gratitude for nature and life is derived. The Dai people worshipped heaven, mountains, water, land, grain, trees, cattle and so on since ancient times. All these show that the Dai ancestors were grateful for their natural needs, which explained their needs in the form of the Dai People's ballads. Finally, the Dai People's sense of gratitude for nature and life has also been transformed into the Enlightenment of people's words and deeds. The Dai People's awe and gratitude nature and life originate from their view that, on the one hand, the nature naturally protect the Dai people; on the other hand, it can also give the Dai people disaster. But the key to be good or bad form the nature for the human is how the people treat nature. 'to be blessed nature and to have happiness, to abuse nature and to have disaster.'

\section{B. The Warning of "Bitterness" in Life}

In the Dai People's ancient ballad, three is the first memory, frequently described, of the Dai People's suffering and pain in the human world. Such as "tiger bite", "big fire burning day", "crying Elegy", "flood" and so on. It recorded the Dai People's experience of suffering. The Dai People's understanding of "bitter" is deeply influenced by the Southern Buddhism. Therefore, "bitter" is understood as the essence of life, and everything that people face is "bitter". This is a basic value judge that the Dai people are realized from the social life and practice of human beings. "Broken and rotten clothes are also bitter; it is also bitter to borrow money without money; no love is bitter;

wanting to get but not get is also bitter; getting but lost is also bitter; being sick but not to look is bitter; being sad but not to be comforted is also bitter; relatives are not harmonious, which is also bitter. "[2] It is the realization of the "bitterness" of the human world causes us to cherish and be grateful for happiness. In the Dai People's ancient Folk Songs, "happiness should not forget the bitter and cutting trees do not forget the axe" expresses the recognition, avoiding suffering and gaining happiness, of the Dai People's suffering and happiness.

\section{The Warning of "Evil" in Behavior}

Ancestors from the Dai people believed that the degree of moral cultivation is directly proportional to the amount of happiness acquired. Therefore, in Folk Songs, there is a saying that "good deeds accumulate good fortune, evil gains evil, accumulating evil will bring pain, who do not cause evil will bring happiness ". In the Dai People' s ancient ballad, it is designed to warn people that extravagant consumption leads to waste, which leads to ecological disasters and no good news. Such as the uncontrolled deforestation caused the collapse of the palace and the wind was raging. Therefore, ancestors from the Dai people obtained the experience and lessons of "destroying forests and destroying themselves". Thus it can be seen that the ancestors of the Dai people associate evil with the gain of happiness, believing that there is a causal link between the two sides and that only people who are good at virtue can gain happiness, and that doing evil will make people suffer endless pain. It is a good thing to warn people that we, only by keeping away from evil and by doing well, can preserve happiness.

\section{THE WARNING FORMS: THE TWO DIFFERENT MODES IN TALENTS CULTIVATION}

The expressive forms of the Dai People's ancient Folk Songs are rich and colorful. They play a role of warning and moral education in laughing and scolding. The moral education and the warning function are always playing a part in real life through the form of whipping and eulogizing. The following two forms are concretely represented:

\section{A. The Warning Function of the Dai People's Ancient} Folk Songs can Play a Role Through Moral Education of Teaching Through lively Activities

The Dai People's ancient ballads are generally circulated through the singing of "zanha" (the singer of the Dai People 's ancient Folk Songs). There are "no zanha, just like eating no salt" in the Dai People's proverbs. Thus, Zanha plays a very important role in the hearts of the Dai people and plays a role in invisible moral education. The Zanha generally knows the Dai people's written language and masters the social, historical, cultural and customs of the Dai nationality, and has been a long-time Buddha or monk. After returning to common customs, they became famous "Zanha" through apprenticing older "Zanha". "Zanha " have some librettos record three aspects: the first is the Dai People's myths; the second is the Dai People's stories of society, history, literature and religion; the third is the Carol, the congratulation, the warning good words, the fable, teachings and the astronomical geography. We can see, from the contents of Zanha's libretto, that "Zanha" is the Encyclopedia of Dai People's society. The Zanha who passes through his own singing book and inherits the history and culture of the Dai people in the music plays a role in an invisible moral teaching through the silent rain.

At present, strengthening the effect of cultivating talents is the focus of education and teaching in the universities. The universities how to play the role of main channel and main position in the cultivation of talents is the problem that university teachers must think about. We take the course of Ideological and political theory in the universities as an example. Whether the ideological and political theory course in the universities can take the form of "full dress" from the Dai People's ancient ballad, break the traditional teaching form of traditional subjects. In the 
traditional ideological and political theory course, teachers need to finish a chapter in one or two classes. Whether we can build several sections of the cultural content in the introduction to the theoretical system of Mao Zedong thought and the socialist theory of Chinese characteristics socialism, one of which is the Dai People's ancient ballad. We should be introduced the Dai ancient ballads in an all-round way, and taught them the Dai ancient ballads. The "ancient song" of the Dai nationality is fragmented and dismembered a number of knowledge points and interest points that conform to the reading habits of college students. Each point of knowledge with corresponding manuscripts, 15 minutes of small video and courseware materials. We upload these data to the school website, which is convenient for everyone to learn after class. The college students can choose the form of learning according to their own preferences. It forms a combination of in class and after class, so that the students can be more easily accepted and recognized, and the moral teaching function is realized. Moral education, which teaches and entertaining, enables students to accept moral norms in implicit education and live in accordance with moral norms.

\section{B. The Warning Function of the Dai People's Ancient Folk Songs can Play a Part by Means of the Concentrated Teaching of Ritual.}

The Dai people is a minority who believe in Buddhism, and the festivals of Buddhism and activities of Buddhism are the best time for the Dai people to accept the traditional moral education. From the first of the year to the end of the year, the Dai People's Buddhist festivals are always carried out, such as "Festival", "white bull", "closing the door Festival", " opening the door Festival", "bathing Buddha Festival", "sacrificing pagoda ", "white elephant", "white firewood", etc. In these celebrations, "zanha" sings the Dai People's Folk Songs, which is an indispensable part.

The Dai people, through these religious festivals and their celebrations, receive intensive education, which have formed a centralized, regular and customary education after a long period of development. The Dai people actively and consciously accept the edification of religious moral education in the Buddhist ritual activities. It becomes the norms of their moral behavior and contributes to the harmonious and orderly social customs of the Dai people.

The ideological and political theory course in the universities can learn from the centralized teaching of Dai people in talents cultivation. The ideological and political theory courses in the universities should have their own independent and exclusive network platform. This platform is not to force college students to watch and learn. The teachers who participate in this platform should be the soul mentors who are committed to sharing their thoughts, ideas, prospects and progress with college students. The platform can be varied in form, and it can be pushed to cover on line and off line. From offline activity to on line interaction, and elaborate field activity (Lecture, salon, etc.) into the form of micro class and mousse, then we put them on the platform. Thus it realizes a variety of options under the line and off the line; this form combines the reality of the students. To carry out targeted educational activities, the content involves a number of aspects: the discussion of the major events at home and abroad, the patriotism education in close combination with the condition of a country and the status of CCP, the education of "three views" in combination with the confusion of the youth. The realization of the centralized Teaching through regular offline activities and online push.

\section{REFERENCES}

[1] Wenpian-Yan,The Dai People's Ancient Ballads, China folk literature and Art Publishing House, Kunming, 1980,pp25.

[2] Kang- Yu,The Dai People's Living Habits and Traditional Culture In Xishuangbanna, Yunnan people's publishing house, Kunming, 2006,pp166. 